\title{
Çocuklarda Özefagus Hastalıklarında Endoskopinin Değeri
}

\author{
Sinan SARI
}

Gazi Üniversitesi Tıp Fakültesi, Çocuk Sağlığı ve Hastalıkları Anabilim Dalı, Çocuk Gastroenteroloji Bilim Dalı, Ankara, Türkiye

Çocuklarda üst ve alt gastrointestinal sisteme ait patolojlerin tanı ve tedavisinde endoskopik incelemeler çok sık kullanılan yöntemlerdir. Teknolojideki ilerlemeler ile çocuklarda özefagogastroduodenoskopinin kullanımı giderek artmaktadır. 1960'ların ikinci yarısında tam fleksible endoskopların geliştirilmesini, 1970'lerin sonlarına doğru çocuk hastalarda kullanıma uygun cihazların üretilmesi izlemiş̧tir (1). Son yıllarda kromoendoskopi, büyütücü (magnifying) endoskopi, konfokal lazer endomikroskopi, dar-bant aralığında görüntüleme (narrow-bandimaging) gibi ilerlemelere rağmen endoskopi sırasında alınan biyopsilerin histopatolojik incelemesi hâlâ tanısal önemini korumaktadır.

Çocuklarda sıklıkla dispeptik yakınmalar, kusma, karın ağrısı, yutma güçlüğü, regürjitasyon, kronik ishal gibi nedenlerle üst gastrointestinal sistem endoskopisi yapılmaktadır (1). Akbulut ve ark. Özefagogastroduodenoskopi yapılan 3081 hastanın değerlendirildiği 6 yıllık seride, özefagusta patoloji saptanan olguların büyük çoğunluğunu kronik karın ağrısı, reflü ve dispepsi yakınmaları ile endoskopi yapılan hastalar oluşturmaktadır (2). Özefagusta patoloji saptanan olguların sadece 1/3'ünde hem endoskopik hem de patolojik bulgular görülürken, 2/3'ünde histopatoloji normal olup sadece endoskopik bulguların saptanması dikkat çekicidir. Olguların çok azında (\%3.6) endoskopi normal iken histopatolojik bulguların olduğu görülmektedir (2).

Endoskopi sırasında yakınmalarla ilișkili özefagus lezyonları görülebileceği gibi özefagus endoskopik olarak tamamen normal olabilir. Bu durumun en tipik örneklerinden biri çocukluk çağının en sık görülen özefagus hastalığı olan gastroözefageal reflüdür (3).Endoskopik olarak özefagus normal görülse de özefagus ilișkili yakınmaları olan hastalarda veya eozinofilik gastrointestinal sistem hastalıkları, Crohn hastalı̆ı gibi gastrointestinal sistemde yaygın tutulumu olabilen hastalıklarda özefagustan yeterli sayıda biyopsi alınması gerektiği unutulmamalıdır. Reflü özefajit düşünülen hastalarda özefagusun distalinden iki biyopsi örneği, eozinofiliközefajit tanısı için üst, orta ve alt özefagustan ikişer, toplamda altı biyopsi örneği alınması önerilmektedir $(3,4)$. Yamalı tutulumu olan veya özefagusta submukoza veya daha derin tabakaları tutan hastalıklarda endoskopi ile alınan mukoza biyopsilerinin tanısal anlamda yeterli olamayabileceği unutulmamalıdır. Endoskopik bulguları olan hastaların büyük çoğunluğunda histopatolojik bulguların normal olmasının diğer nedenleri arasında rutin olarak alınan iki adet milimetrik biyopsinin özefagusun tamamını temsil etmemesi ve özefagusun tübüler yapısı nedeni ile yeterli kalitede biyopsi örneğinin alınamaması sayllabilir.

\section{KAYNAKLAR}

1. Schaeppi MG, Mougenot J, Belli DC. Upper Gastrointestinal Endoscopy. In: Walker WA, Goulet O, Kleinman RE, Sherman PM,Shneider BL,Sanderson IR (eds). Pediatric Gastrointestinal Disease,4th ed. BC Decker 2004:1674-702.

2. Akbulut UE, Sağ E, Çakır M. Özefagogastroduodenoskopi yapılmış çocuklarda özefagus patolojilerinin değerlendirilmesi. Türkiye Çocuk Hast Derg 2017;11;9-14.

3. Vandenplas Y, Rudolph CD, Di Lorenzo C, Hassall E, Liptak G, Mazur L, et al. J Pediatr Gastroenterol Nutr 2009;49:498547.

4. Papadopoulou A, Koletzko S, Heuschkel R, Dias JA, Allen KJ, Murch SH, et al. Management guidelines of eosinophilicesophagitis in childhood. J Pediatr Gastroenterol Nutr. 2014;58:107-18. 